\title{
Night, light and flight: light attraction in Trichoptera
}

Malin Larsson, Anders Göthberg and Per Milberg

The self-archived postprint version of this journal article is available at Linköping University Institutional Repository (DiVA):

http://urn.kb.se/resolve?urn=urn:nbn:se:liu:diva-160592

N.B.: When citing this work, cite the original publication.

Larsson, M., Göthberg, A., Milberg, P., (2019), Night, light and flight: light attraction in Trichoptera, Insect Conservation and Diversity. https://doi.org/10.1111/icad.12379

Original publication available at:

https://doi.org/10.1111/icad.12379

Copyright: Wiley (12 months)

http://eu.wiley.com/WileyCDA/ 


\section{Night, light and flight: light attraction in Trichoptera}

Malin Larsson, Anders Göthberg, Per Milberg*

IFM Biology, Conservation Ecology Group, Linköping University, SE-581 83 Linköping, Sweden

* Corresponding author

Running head: Light attraction in Trichoptera

Conflict of interest: non 


\section{Abstract}

1. Artificial light is an important and necessary part of urban environments, but light can have substantial direct and indirect effects on populations of various organisms. Urban areas are often situated close to water and thus organisms dependent on water could be especially vulnerable. Trichoptera is one of the most abundant insect orders in freshwater but its attraction to light has not been analysed in detail.

2. We contrasted catches in light traps and passive traps at three locations in Sweden.

3. The results showed that artificial light can affect Trichoptera populations. Attraction to light varied between Trichoptera species and females were more attracted than males. Day-, evening- and especially night-active species were all attracted to light. Light catches of day- and evening-active Trichoptera could partly be a consequence of atypical flight activity, i.e. they are deceived to take flight when a lamp is lit during night.

4. In all, artificial light can alter Trichoptera populations, sex ratios and species composition. This impact should be considered when erecting and managing light sources near waterways.

Keywords: Trichoptera; light attraction; artificial light; biodiversity; insects

\section{Introduction}

As artificial light has become an integral part of urban environments (Degen et al. 2016) concerns about its effect on nature have increased. Attraction to light is a problem as many insect species cannot resist the stimulus of light (Eisenbeis 2006). Artificial light can decrease biodiversity as it changes insects' behaviour and it can have a direct lethal effect (Altermatt et al. 2009, Hölker et al. 2010, Perkin et al. 2011, Grubisic et al. 2018). Direct effects include burning, increased predation (Frank 2006, Altermatt et al. 2009), overheating, and 
dehydration (Frank 2006). Eisenbeis (2006) estimated that the death rate of insects at artificial light sources is approximately $33 \%$. Artificial light might also reduce populations indirectly by altering behaviours such as mating, oviposition and migration (Eisenbeis 2006). More than $50 \%$ of moths approaching a light source stops on the ground and cannot escape the near zone of lighting (Eisenbeis 2006). In moths, species and sexes attract differently to light (Altermatt et al. 2009, Merckx \& Slade 2014). Light is expected to affect sexes differently if one sex flies more actively and thus has a larger risk of passing an artificial light source (Altermatt et al. 2009). A population can also be affected demographically as young specimens are more likely to fly to light than old ones (Frank 2006). Introducing artificial light to a new area could thus change species composition by increased mortality for some species but not others, and also alter sex ratios.

The effect of artificial light can be particularly significant for freshwater systems as many people live around fresh water (Perkin et al. 2014). Trichoptera is one of the most abundant freshwater insect groups (Roy \& Harper 1981, Hirabayashi et al. 2011) and like 60\% of invertebrates, many Trichoptera species are nocturnal (Hölker et al. 2010, Barnard \& Ross 2012, Nowinszky et al. 2012, Gullefors 2016). However, not all Trichoptera are night-active and Svensson (1972) proposed that day-active species should not be attracted to light and thus would not be disturbed by artificial light, but we have found no evaluation of Svensson's hypothesis. The diurnal flight patterns of Trichoptera species has recently been classified by Gullefors (2016).

The aim of this study was to investigate how artificial light influence Trichoptera species and their sex ratio. Which Trichoptera species are attracted to light? Are day-active species less attracted to light as suggested by Svensson (1972)? Is one sex more attracted to light than the other? The result of this study can be used to evaluate the impact of artificial light and to assess the degree of bias when sampling Trichoptera using light. 


\section{Material and methods}

\section{Sampling}

Material was collected with one light trap and one non-attracting (=passive) trap at three sites in Sweden (Table 1). Sampling in 2016 at Pjältån was performed by ML with the passive trap approximately $100 \mathrm{~m}$ upstream of the light trap and both traps placed at slight riffles. A second site was sampled in 1972 and 1973 by AG at Rickleån and the two years were considered as separate data sets in the analyses. A third site was sampled in 1974 by AG at Kaltisjokk. Kaltisjokk was a tributary to the river Stora Lule älv but has since been completely drained. Two pairs of traps were used from this location; one pair in fast flowing water and one at a less steep gradient. The data from the two pairs of traps were considered as separate data sets in the analyses.

The passive trap at Pjältån was a Malaise-trap, a tent-like structure of nets which led insects into a container where they could be sampled. At Kaltisjokk, the passive traps consisted of large window traps spanning the width of the watercourse. The window traps were approximately $1 \mathrm{~m}$ high and several metres wide and insects impacting the glass fell into trays at the bottom where they could be sampled. At Rickleån, the passive trap consisted of a suction trap, which sampled passing insects by using an air stream pulling them into a container. The light traps at all sites involved the attraction of a light source to lure insects into a container for sampling. The light trap at Pjältån and Kaltisjokk was according to Olsson (1971). At Pjältån, a 15 W incandescent light tube was used. The light trap at Rickleån was according to Müller \& Ulfstrand (1970).

Specimens were identified to species and sexed. Species from Rickleån and Kaltisjokk were identified by AG mainly according to MacLachlan (1874-80), Mosely (1939), Tobias (1972) and Macan \& Worthington (1973). For Pjältån, specimens were identified by ML and AG 
according to Malicky (2010), Macan \& Worthington (1973), and Tobias (1972). Research on flight activity periodicity has shown some Trichoptera species having a known diurnal rhythm. We classified species as day-, evening-, or night-active according to Gullefors (2016) and species with unknown diurnal rhythm as unclassified.

\section{Statistical analyses}

Meta-analysis was performed on the natural logarithm of odds ratio with $95 \%$ confidence interval $\left(\mathrm{CI}_{95 \%}\right)\left(\right.$ Formula 1): $\mathrm{LN}\left(\right.$ Odds $\left._{\mathrm{L}} / \mathrm{Odds}_{\mathrm{P}}\right) \pm 1.96 \times \mathrm{SE}(1)$ with Odds $_{\mathrm{L}}=$ Light $_{\mathrm{i}} / \sum \mathrm{Light}$ for species with specimens $\leq 20 \%$ of the total and Light $t_{i}$ represent the number of specimens per species in light trap, and Oddsp $=$ Passive $_{\mathrm{i}} / \sum$ Passive for species with specimens $\leq 20 \%$ of the total and Passive $e_{i}$ represent the number of specimens per species in passive trap. $\mathrm{CI}_{95 \%}$ was calculated with $\mathrm{SE}=\sqrt{ }\left(1 /\right.$ Light $_{i}+1 / \sum$ Light $+1 /$ Passive $_{i}+1 / \sum$ Passive $)$.

Species whose specimens comprised $20 \%$ or more of the catch were excluded from the data set when calculating odds ratio for light attraction per species so not to skew the result for the less abundant species. For the abundant species ( $\geq 20 \%)$ which occurred at all sampling sites (Hydropsyche siltalai and Rhyacophila nubila), attraction to light was analysed separately and the total sum included the abundant species.

The sex ratio was analysed through meta-analysis on the odds ratio with $\mathrm{CI}_{95 \%}$ on all species, including the dominant ones (formula 2). $\mathrm{LN}\left(\mathrm{Odds}_{\mathrm{F}} / \mathrm{Odds}_{\mathrm{M}}\right) \pm 1.96 \times \mathrm{SE}(2)$ with $\operatorname{Odds}_{\mathrm{F}}=$ $\mathrm{F}_{\text {Light }} / \mathrm{F}_{\text {Passive }}$ for $\mathrm{F}=$ number of females, and $\mathrm{Odds}_{\mathrm{M}}=\mathrm{M}_{\mathrm{Light}} / \mathrm{M}_{\text {Passive }}$ for $\mathrm{M}=$ number of males. $\mathrm{CI}_{95 \%}$ was calculated with $\mathrm{SE}=\sqrt{ }\left(1 / \mathrm{F}_{\text {Light }}+1 / \mathrm{F}_{\text {Passive }}+1 / \mathrm{M}_{\text {Light }}+1 / \mathrm{M}_{\text {Passive }}\right)$.

All meta-analyses on light attraction was performed based on species and data set (the values were calculated for Species 1 Data set 1, then Species 1 Data set 2, Species 1 Data set 3, etc.). 
The results per species and data set were then compiled with subgrouping for the final results. Subgrouping was done on four levels: in total, per activity class, per family, and per species.

Meta-analysis was performed in the software R version 3.3.1 (R Core Team 2016). The results from the five sets of data were compiled by meta-analysis with the package "metafor" (Viechtbauer 2010). For all meta-analyses, the method of residual maximum likelihood (REML) was used to fit the model.

Few studies have compared results from attracting (light or pheromone) and non-attracting (passive) trap (Scanlon \& Petit 2008), and we have found no studies on the efficiency of different trap types for Trichoptera. Worth noting is that in previous studies on Trichoptera absolute abundances have been used. However, trap efficiency can differ greatly between light traps and passive traps. At Pjältån, only $3 \%$ of the specimens were caught in the passive trap. Species found in both traps will thus seem more attracted to light when using absolute abundance. To compensate for any difference in trap efficiency, we used relative abundance. This approach has not previously been used, so results are not directly comparable with other studies.

\section{Results}

In total, 131 species and more than 90000 specimens were analysed (Table 2, Appendix A). Five species were caught in passive traps only, but only Adicella reducta was represented by more than two specimens. In comparison, 38 species were caught in light traps only.

\section{Species' attraction to light}

Thirteen species occurred in all five data sets, and two of these species dominated in at least one of the samples, i.e. compromised $20 \%$ or more of the specimens caught. These two species (Hydropsyche siltalai and Rhyacophila nubila) were analysed separately (see 
methods). Both these species are classified as night-active. Of the remaining eleven species, three were day-active, four evening-active, three night-active and one was unclassified.

Hydropsyche siltalai showed an attraction to light at Rickleån (both years) and Pjältån (Figure 1). Rhyacophila nubila showed an attraction to light in all data sets apart from Pjältån (Figure $1)$.

The meta-analysis showed that Trichoptera in general were more often caught in light traps compared to passive traps. Night-active species were most attracted to light and eveningactive species least so (Figure 2).

\section{Sexes' attraction to light}

Females had a tendency to be more attracted to light than males (Figure 3). In evening- and day-active species this was significant (i.e. $\mathrm{CI}_{95 \%}$ does not overlap zero), but in night-active species no difference in light attraction between sexes was found.

Among sixteen taxonomic families found, females of Glossosomatidae, Hydroptilidae, Lepidostomatidae, and Psychomyiidae were more attracted to light than males but in Limnephilidae and Molannidae males were more attracted to light than females (Figure 4).

\section{Discussion}

\section{Light attraction in general and per species}

Trichoptera as a group was strongly attracted to light, and populations could therefore be seriously reduced when artificial light is used close to freshwater. Even though the overall pattern was of light attraction, not all species were equally attracted. Four of the eleven species present in all data sets were attracted to light, while two avoided them. Other insects

have equally variable pattern, and Taylor \& Carter (1961) found one species being 5000 times 
more probable to fly to light than another. In our study light attraction differed with the same magnitude, with Apatania stigmatella being about 5500 times more likely to fly to light than Lype phaeopa (comparison of samples in Rickleån 1972, with similar traps as those used by Taylor \& Carter 1961).

That light affects species differently can be seen in many organisms, from moths and beetles (Rich \& Longcore 2006) to mammals (Rowse et al. 2016). For example, species of forestdwelling bats avoid lit areas, while other bat species may use artificial light for foraging (Rowse et al. 2016). Although the majority of Trichoptera species were attracted to light eighteen percent of the species had a larger relative presence in passive traps than in light traps, showing an avoidance of light. A handful of species were exclusively caught in passive traps, which suggests even stronger that some, for example Adicella reducta, avoid light. Svensson (1972) caught several species in higher numbers in passive traps than in light traps and Smith et al. (2002) identified eleven species in passive traps only. In our analysis, species recorded in passive traps only were rare (singletons and doubletons) with the exception of Adicella reducta. Hence, even if light avoidance exists in Trichoptera, it seems a rare phenomenon.

However, it is not completely straightforward to analyse the avoidance of light. It is not unusual that light causes a dazzling effect with insects landing on the ground, immobilised by the light source for hours, sometimes the remainder of the night (Frank 2006, Rowse et al. 2016). This is a light effect not reflected in trap catches. For insects which fly only for a part of night and do not live for long periods, such as Trichoptera, an immobilization could be costly through delay of mating and oviposition (Frank 2006).

In our data, even day-active species were attracted to light, contradicting the hypothesis by Smith et al. (2002) that day-flying species are caught in passive traps only, because they are 
not attracted to light. However, Smith et al. did not test their hypothesis. In laboratory experiments, Trichoptera has species-specific reactions to any change from light to dark and dark to light (Jackson \& Resh 1991). Some have a photonegative response where light inhibited their flight activity (Jackson \& Resh 1991). Other species (both day- and nightactive) react on lights being turned on by increasing their flight activity (Jackson \& Resh 1991). This means that light traps can create an artificial, higher flight activity even in dayactive species. In one species, sexes reacted differently to light being turned on (Jackson \& Resh 1991), which indicates a similar artificial product when analysing differences between sexes. Furthermore, Andersen (1979) noted that Philopotamus montanus appeared nightactive in light traps and day-active in suction traps. Hence, light traps can cause an atypical diurnal flight activity pattern, and recorded light preference for day- and evening-active species might be an artefact of sampling rather than an evolutionary trait. In the perspective of light pollution, on the other hand, any type of light-induced flight activity is expected to be negative.

In summary, light can affect Trichoptera in at least three ways: to attract to a light source, to paralyze and immobilise, and to initiate flight in day-active species (creating an atypical flight activity). Irrespective of mechanisms, light is likely to affect a wide range of species and this irrespective of their typical flight activity pattern.

\section{Light attraction in males and females}

Females were generally more attracted to light than males in our data, which is the opposite pattern from moths (Altermatt et al. 2009). Of thirteen species which occurred in all five data sets, females of five species were significantly more attracted to light than males ( $\mathrm{CI}_{95 \%}$ does not overlap zero), while in one species males were more attracted to light than females. When one sex experiences higher mortality than the other, an unequal sex ratio is created and the 
effective size of the population is reduced (Frankham 1995). Males can usually fertilize many females, but when females have high mortality the population can be reduced as fewer clutches are produced (Grübler et al. 2008). A small effective population size can decrease the genetic variation and risk inbreeding and genetic drift (Frankham 1995), which can make the population less able to adapt to changes in the environment in the long term (Harris et al. 2017). Strong attraction to light in females therefore can have a larger impact on population structure than would be assumed if only the overall effect is considered.

It is known that sex ratio in Trichoptera is not always equal and the ratio varies with species (Harris 1971, Crichton et al. 1978, Smith et al. 2002, Nowinszky et al. 2014). The uneven sex ratio found in trapped adults has been considered a sampling artefact (Smith et al. 2002) or being due to higher mortality for males in larval or pupal phases (Waringer 2003). Our data included more females than males in absolute numbers, especially in light traps. The metaanalysis of odds ratios showed that females of day- and evening-active species were significantly more attracted to light while neither sex in night-active species were more attracted than the other. The sex ratio has rarely been compared between light and passive traps, and never based on relative abundance. Svensson (1972) found higher proportion of males than females in light traps and the opposite in passive traps. Crichton et al. (1978) found higher proportion of male Trichoptera in light traps but noted that some species differed from this pattern. In contrast, Harris (1971) found $65 \%$ females in light traps, and fourteen of the sixteen most common species had higher proportion of females. Smith et al. (2002) found more females than males in both light and passive traps. Hence, our results both confirm and conflict with results reported in previous studies. 


\section{Methodological considerations}

Comparisons between studies are complicated when different methods and analyses are used.

We found about twice as many species in light traps compared to passive traps and in most data sets more specimens were caught in light traps, but our window traps caught more specimens than light traps. Svensson (1972) found more specimens in light traps, and only a few species were more common in passive traps. Smith et al. (2002) presented opposite results and found both more species and more specimens in passive traps than in light traps. Both Svensson (1972) and Smith et al. (2002) used malaise traps. Our study compiled data collected with suction traps, window traps and malaise traps. It seems likely that the traps' efficiency vary among studies, making absolute numbers caught an inappropriate endpoint. Our study also indicated that trap type had an effect on absolute numbers. Furthermore, the type of light source can affect the catch (Wakefield et al. 2018). Using relative abundance and meta-analysis approach minimize the influence of differing efficiency between studies and trap types.

Light attraction per sex and the sex ratio of Trichoptera also differ between studies. In five studies where the sex ratio in several types of traps was evaluated, Svensson (1972) and Crichton et al. (1978) found more males than females while Harris (1971), Smith et al. (2002) and the current study found more females than males. Two major factors were identified in studies with more males than females; 1) catches were dominated by limnephilids and 2) most traps were placed relatively far from water. Firstly, the only species in our meta-analysis with a higher male ratio in light traps was a limnephilid and it was a general trait of this family that males were more attracted to light than females. Limnephilids are medium to large species with strong flight ability, often found far from their larval habitats (Crichton et al. 1978) and even far from water (Crichton \& Fischer 1982). Secondly, Svensson (1972) noted that much fewer females were found in traps far from water. In a study on moths, traps close to the larva 
host trees only caught females while males dominated in traps far from the host plants (Frank 2006). Thus, traps far from the larval habitat can bias towards males. In Trichoptera, a domination of females could thus be due to proximity of traps to the stream. In those studies where females dominated, light traps were situated close to water (Harris 1971, Smith et al. 2002). Females also dominated in our sampling where all traps were situated in proximity to the stream. Thus, sampling strategy must be considered when evaluating light attraction and sex ratio in Trichoptera.

\section{Conclusions}

As a group, Trichoptera was strongly attracted to light but some species seemed to avoid it. Night-active species were more attracted to light than day- and evening-active species. Females had a tendency to be more attracted to light than males. Apart from the ecological consequences of light pollution, it is also apparent that design and evaluation of both sampling and monitoring of Trichoptera using light traps need to consider differing light attraction among species.

\section{References}

Altermatt F, Baumeyer A, Ebert D (2009) Experimental evidence for male biased flight-tolight behavior in two moth species. Entomologia Experimentalis et Applicata 130, 259-265 Andersen T (1979) Some caddis flies (Trichoptera) in western Norway, and their arrival pattern in light traps. Fauna Norvegica 26, 12-17

Barnard P, Ross E (2012) The adult Trichoptera (caddisflies) of Britain and Ireland Handbooks for the Identification of British Insects Vol 1 Part 17. FSC Publication: Telford 
Crichton MI, Fisher D, Woiwod IP (1978) Life histories and distribution of British Trichoptera, excluding Limnephilidae and Hydroptilidae, based on the Rothamsted Insect Survey. Holarctic Ecology 1, 31-45

Crichton MI, Fischer DB (1982) Records of caddis flies (Trichoptera) from Rothamsted light traps at field centres. Field Studies 5, 569-579

Degen T, Mitesser O, Perkin EK, Weiss N-S, Oehlert M, Mattig E, Hölker F (2016) Street lighting: sex-independent impacts on moth movement. Journal of Animal Ecology 85, 13521360

Eisenbeis G (2006) Artificial night lighting and insects: attraction of insects to streetlamps in a rural setting in Germany. pp 281-304 in: Rich C, Longcore T (eds) Ecological consequences of artificial night lighting. Island Press, Washington DC

Frank KD (2006) Effects of artificial night lighting on moths. pp 305-344: in Rich C, Longcore T (eds) Ecological consequences of artificial night lighting. Island Press, Washington DC

Frankham R (1995) Effective population size/adult population size ratios in wildlife: a review. Genetical Research 66, 95-107

Grubisic M, van Grunsven RHA, Kyba CCM, Manfrin A, Hölker F (2018) Insect declines and agroecosystems: does light pollution matter? Annals of Applied Biology 173, 180-189

Grübler MU, Schuler H, Müller M, Spaar R, Horch P, Nae-Daenzer B (2008) Female biased mortality caused by anthropogenic nest loss contributes to population decline and adult sex ratio of a meadow bird. Biological Conservation 141, 3040-3049 
Gullefors B (2016) Dag-, kvälls- och nattflygande nattsländor (Trichoptera) I Sverige.

Entomologisk Tidskrift 137, 137-146

Harris LN, Palstra FP, Bajno R, Gallagher CP, Howland KL, Taylor EB, Reist JD (2017)

Assessing conservation risks to populations of an anadromous Arctic salmonid, the northern

Dolly Varden (Salvelinus malma malma), via estimates of effective and census populations

sizes and approximate Bayesian computation. Conservation Genetics 18, 393-410

Harris T (1971) Crepuscular flight periodicity of Trichoptera. Journal of the Kansas

Entomological Society 44, 295-301

Hirabayashi K, Kimura G, Inoue E (2011) Adult caddisflies (Trichoptera) attracted to artificial lights in the middle reaches of the Shinano River from 2005 to 2007. Zoosymposia $5,143-146$

Hölker F, Wolter C, Perkin EK, Tockner K (2010) Light pollution as a biodiversity threat. Trends in Ecology and Evolution 25, 681-682

Jackson JK, Resh VH (1991) Periodicity in mate attraction and flight activity of three species of caddisflies (Trichoptera). Journal of the North American Benthological Society 10, 198209

Macan TT, Worthington CJ (1973) A key to the adults of the British Trichoptera. Freshwater Biological Association 28

MacLachlan R (1874-80) A monographic revision and synopsis of the Trichoptera of the European Fauna. - EW Classey Ltd, Hampton, Middlesex.

Malaise R (1937) A new insect-trap. Entomologisk Tidskrift 58, 148-160 
Malicky H (2010) Atlas of European Trichoptera. 2d ed. Springer, Dordrecht

Merckx T, Slade EM (2014) Macro-moth families differ in their attraction to light: implications for light-trap monitoring programmes. Insect Conservation and Diversity 7, 453461

Mosely M E (1939) The British caddis flies (Trichoptera). A collector's handbook. Routledge, London.

Müller K, Ulfstrand S (1970) Die Tagesperiodik der Flugaktivität von Philopotamus montanus Don. Und Rhyacophila nubila Zett. (Trichoptera). OIKOS 13, 80-86

Nowinszky L, Kiss O, Szentkiralyi F, Puskas J, Ladanyi M (2012) Influence of Illumination and polarized moonlight on light-trap catch of caddisflies (Trichoptera). Research Journal of Biology 2, 79-90

Nowinszky L, Kiss O, Puskas J (2014) Swarming patterns of light trapped individuals of caddisfly species (Trichoptera) in Central Europe. Central European Journal of Biology 9, $417-430$

Olsson T (1971) Ljusfällefångst av Trichoptera och Plecoptera vid Rickleån 1970. Rapport från Rickleå fältstation 23: 1-31. Umeå Universitet

Perkin EK, Hölker F, Richardson JS, Sadler JP, Wolter C, Tockner K (2011) The influence of artificial light on stream and riparian ecosystems: questions, challenges, and perspectives. Ecosphere 2, 1-16

Perkin EK, Hölker F, Tockner K (2014) The effects of artificial lighting on adult aquatic and terrestrial insects. Freshwater Biology 59, 368-377 
R Core Team (2016). R: A language and environment for statistical computing. R Foundation for Statistical Computing, Vienna, Austria. URL: https://www.R-project.org/

Rich C, Longcore T (2006) Ecological consequences of artificial night lighting. Island Press, Washington DC

Rowse EG, Lewanzik D, Stone EL, Harris S, Jones G (2016) Dark matters: the effects of artificial lighting on bats. pp 187-214 in: Voight CC, Kingston T (eds) Bats in the Anthropocene: Conservation of bats in a changing world. Springer Open, New York Roy D, Harper PP (1981) An analysis of an adult Trichoptera community in the Laurentian highlands of Quebec. Holarctic ecology 4, 102-115

Scanlon A, Petit S (2008) Biomass and biodiversity of nocturnal aerial insects in an Adelaide City par and implications for bats (Microchiroptera). Urban Ecocystem 11, 91-106

Smith B, Collier KJ, Halliday NJ (2002) Composition and flight periodicity of adult caddisflies in New Zealand hill-country catchments of contrasting land use. New Zealand Journal of Marine and Freshwater Research 36, 864-878.

Svensson BW (1972) Population movements of adult Trichoptera at a South Swedish stream. Oikos 25, 157-175

Taylor LR, Carter CI (1961) The analysis of numbers and distribution in an aerial population of macrolepidoptera. Transactions of the Royal Entomological Society of London 113, 369386

Tobias W (1972) Zur Kenntnis europäischer Hydropsychidae (Insecta: Trichoptera). Senckenbergiana Biologica 53, 245-268 
Viechtbauer W (2010). Conducting meta-analyses in R with the metafor package. Journal of Statistical Software, 36 1-48. URL: http://www.jstatsoft.org/v36/i03/

Wakefield A, Broyles M, Stone EL, Harris S, Jones G (2018) Quantifying the attractiveness of broad - spectrum street lights to aerial nocturnal insects. Journal of Applied Ecology 55, $714-722$

Waringer, JA (2003) Light-trapping of caddisflies at the Thaya (Lower Austria), a river influence by pulsating hypolimnetic water release. International Review of Hydrobiology 88, $139-153$ 


\section{Figure legends}

Figure 1. Meta-analysis of trap preference for Hydropsyche siltalai and Rhyacophila nubila, the two species which dominated $(>20 \%)$ in one or more data sets of adult Trichoptera in Sweden. Diamonds represent weighted averages, and bars $\mathrm{CI}_{95 \%}$.

Figure 2. Meta-analysis of trap preference of adult Trichoptera in Sweden based on all data sets and excluding dominant species. Diamonds represent weighted averages, and bars $\mathrm{CI}_{95 \%}$. Summaries for activity classes include all species, but only species which occurred in all data sets are shown separately.

Figure 3. Meta-analysis of light attraction of adult Trichoptera in Sweden according to sex ratio. Diamond shapes represent weighted average, and bars $\mathrm{CI}_{95 \%}$. For activity classes the summary was made on all species, but only those species which occurred in all data sets are shown separately.

Figure 4. Meta-analysis of sex differences in light attraction in Trichoptera families in Sweden. Bars represent $\mathrm{CI}_{95 \%}$. 


\section{Hydropsyche siltalai}

Survey, Year

Rickleån, 1972

Rickleån, 1973

Kaltisjokk 1, 1974

Kaltisjokk 2, 1974

Pjältån, 2016

Total (Hydropsyche siltalai)

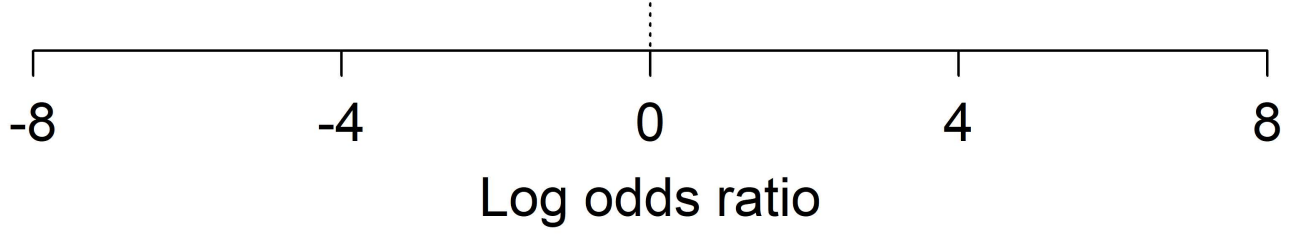

\section{Rhyacophila nubila}

Survey, Year

Not attracted to light

Attracted to light

Rickleån, 1972

Rickleån, 1973

Kaltisjokk 1, 1974

Kaltisjokk 2, 1974

Pjältån, 2016

Total (Rhyacophila nubila)

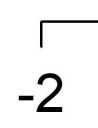

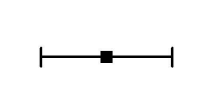

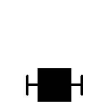

$\mapsto-1$
-

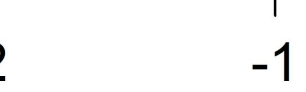

$-1$ 
Unclassified species $(n=63)$

Hydroptila simulans

Night-active species $(n=35)$

Potamophylax cingulatus

Lepidostoma hirtum

Ceraclea dissimilis

Evening-active species $(n=16)$

Wormaldia subnigra

Polycentropus irroratus

Neureclipsis bimaculata

Lype phaeopa

Day-active species ( $n=15$ )

Polycentropus flavomaculatus

Ithytrichia lamellaris

Hydroptila tineoides

Total

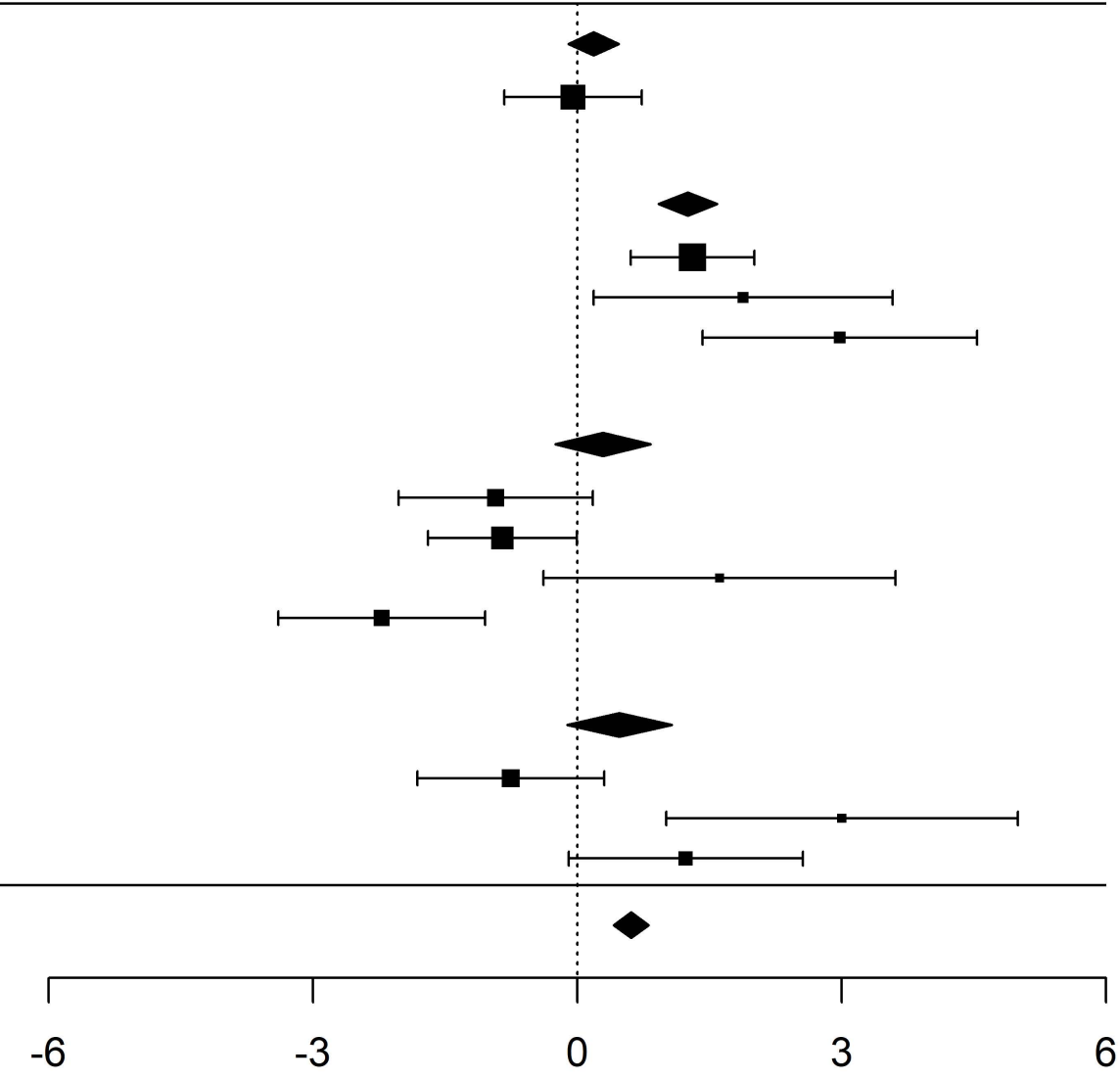

Log odds ratio 
Unclassified species $(n=64)$

Hydroptila simulans

Night-active species $(n=35)$

Rhyacophila nubila

Potamophylax cingulatus

Lepidostoma hirtum

Hydropsyche siltalai

Ceraclea dissimilis

Evening-active species $(n=16)$

Wormaldia subnigra

Polycentropus irroratus

Neureclipsis bimaculata

Lype phaeopa

Day-active species $(n=15)$

Polycentropus flavomaculatus

Ithytrichia lamellaris

Hydroptila tineoides

Total

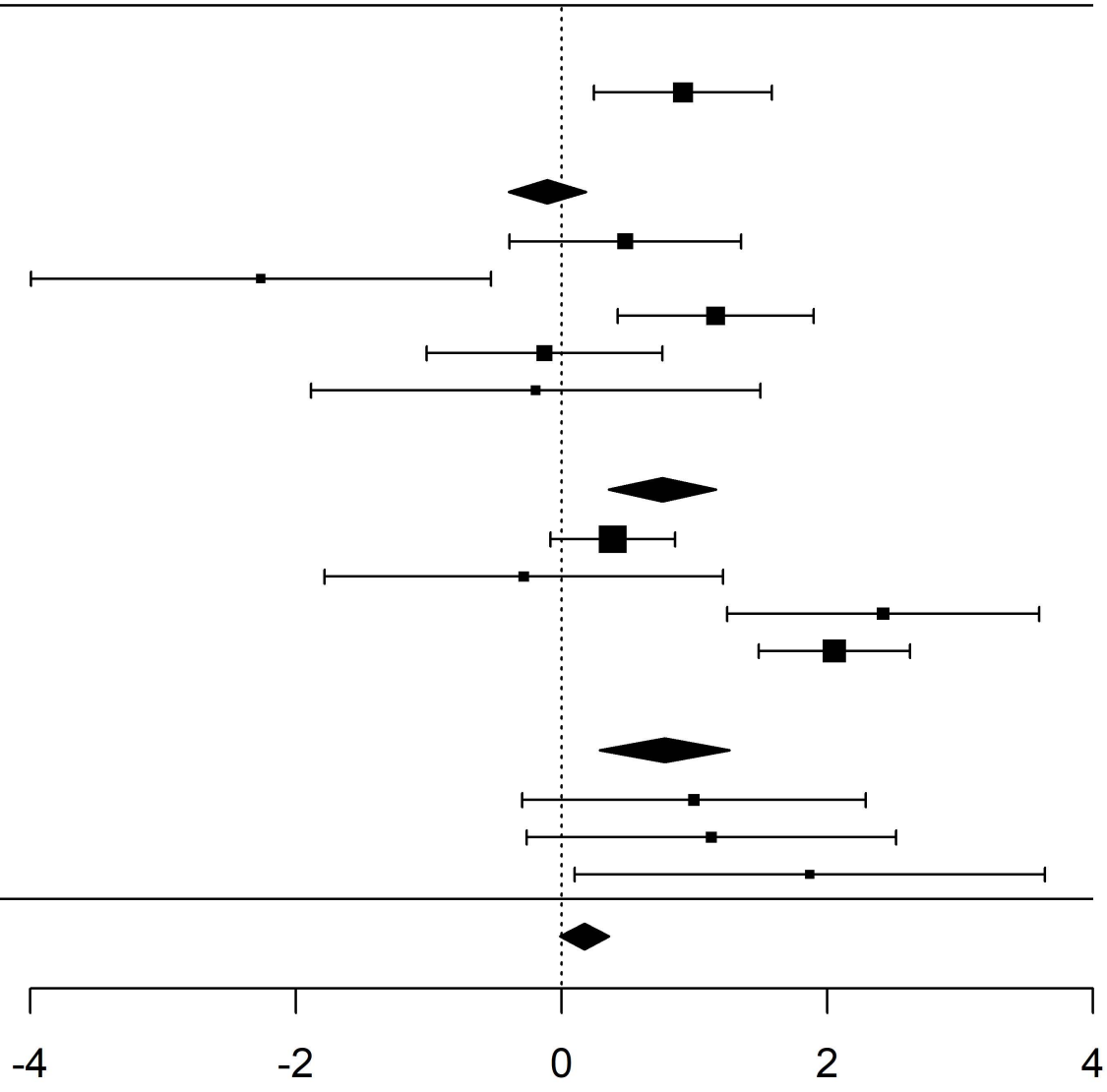

Log odds ratio 


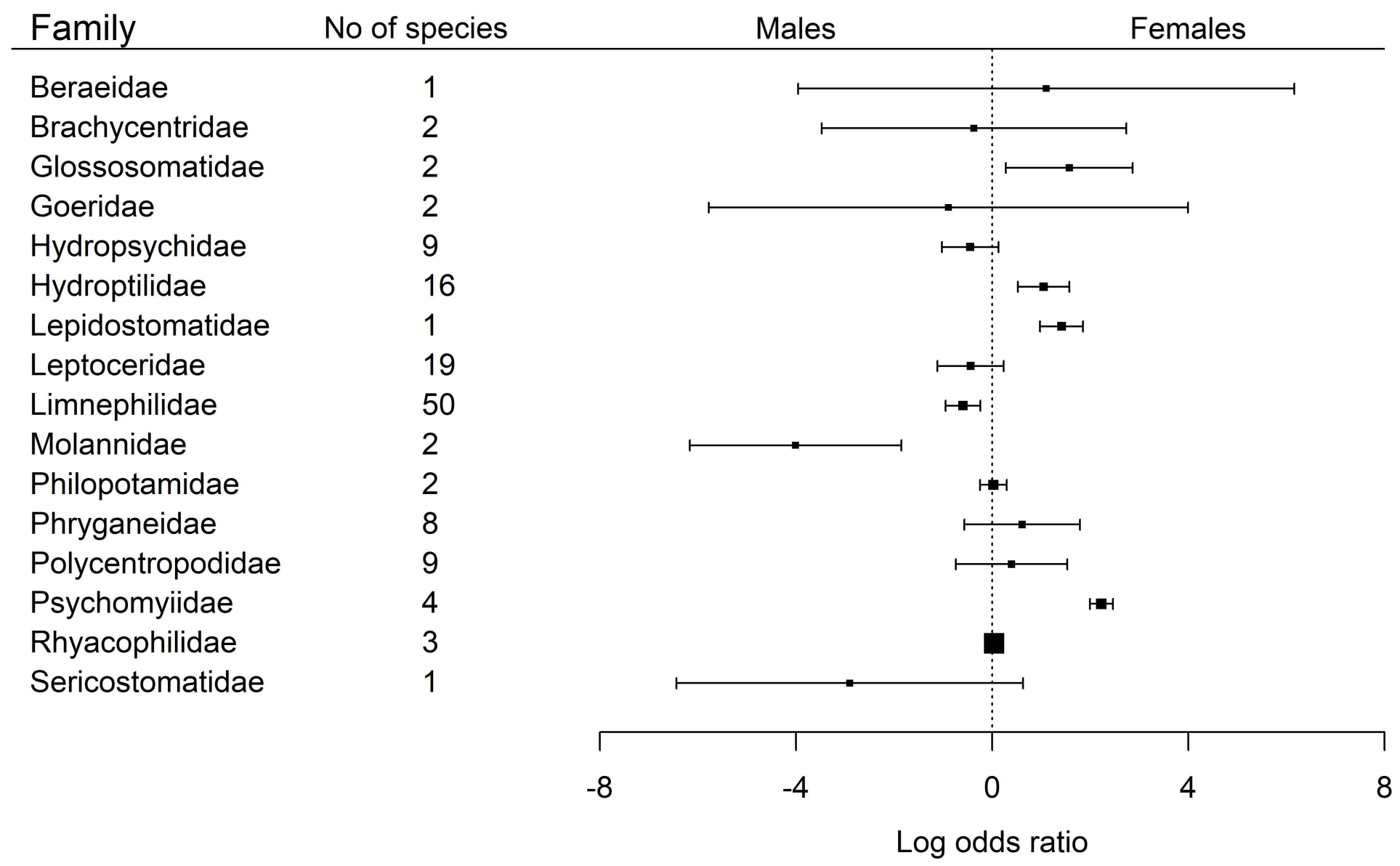


Table 1. Descriptive information of the three sampling sites in Sweden.

\begin{tabular}{|c|c|c|c|c|c|c|}
\hline & Region & Year & $\begin{array}{c}\text { Passive } \\
\text { trap }\end{array}$ & Coordinates & $\begin{array}{c}\text { Mean } \\
\text { discharge } \\
\text { (modelled) }\end{array}$ & $\begin{array}{c}\text { Catchment } \\
\text { area }\end{array}$ \\
\hline Pjältån & South & 2016 & Malaise* & $\begin{array}{l}6506552, \\
566763\end{array}$ & $0.5 \mathrm{~m}^{3} \mathrm{~s}^{-1}$ & $64 \mathrm{~km}^{2}$ \\
\hline Rickleån & Middle & $1972-73$ & Suction** & $\begin{array}{l}7120240 \\
789249\end{array}$ & $16.4 \mathrm{~m}^{3} \mathrm{~s}^{-1}$ & $1600 \mathrm{~km}^{2}$ \\
\hline Kaltisjokk & North & 1974 & Window & $\begin{array}{l}7406670, \\
736631\end{array}$ & $1.2 \mathrm{~m}^{3} \mathrm{~s}^{-1}$ & $90 \mathrm{~km}^{2}$ \\
\hline
\end{tabular}

Coordinates are given in Sweref99 TM N,E. Catchment area and mean discharge was acquired through SMHI (Swedish Meteorological and Hydrological Institute).

* cf Malaise 1937; modernized with plastic containers for capture in liquid. ** cf Müller \& Ulfstrand 1970. 
Table 2. Descriptive information of five data sets of adult Trichoptera in Sweden.

\begin{tabular}{|c|c|c|c|c|c|}
\hline & Pjältån & $\begin{array}{c}\text { Rickleån } \\
\text { (1972) }\end{array}$ & $\begin{array}{c}\text { Rickleån } \\
\text { (1973) }\end{array}$ & $\begin{array}{c}\text { Kaltisjokk } \\
1\end{array}$ & $\begin{array}{c}\text { Kaltisjokk } \\
2\end{array}$ \\
\hline No. of species total & 60 & 86 & 86 & 56 & 47 \\
\hline Light traps & 57 & 81 & 81 & 50 & 41 \\
\hline Passive traps & 28 & 46 & 42 & 35 & 32 \\
\hline Specimens in total & 30550 & 20671 & 15372 & 18306 & 7527 \\
\hline Light traps & $97 \%$ & $81 \%$ & $76 \%$ & $40 \%$ & $43 \%$ \\
\hline Females & $63 \%$ & $56 \%$ & $53 \%$ & $44 \%$ & $57 \%$ \\
\hline
\end{tabular}

